\title{
Therapeutic approach of adipose-derived mesenchymal stem cells in refractory peptic ulcer
}

\author{
Mahshid Saleh ${ }^{1}$, Amir Ali Sohrabpour², Mohammad Reza Mehrabi ${ }^{3}$ Iman Seyhoun ${ }^{1}$ and Amir Abbas Vaezi ${ }^{4^{*}}$ (i)
}

\begin{abstract}
Peptic ulcer is one of the most common gastrointestinal tract disorders worldwide, associated with challenges such as refractory morbidity, bleeding, interference with use of anticoagulants, and potential side effects associated with long-term use of proton pump inhibitors. A peptic ulcer is a defect in gastric or duodenal mucosa extending from muscularis mucosa to deeper layers of the stomach wall. In most cases, ulcers respond to standard treatments. However, in some people, peptic ulcer becomes resistant to conventional treatment or recurs after initially successful therapy. Therefore, new and safe treatments, including the use of stem cells, are highly favored for these patients. Adipose-derived mesenchymal stem cells are readily available in large quantities with minimal invasive intervention, and isolation of adipose-derived mesenchymal stromal stem cells (ASC) produces large amounts of stem cells, which are essential for cell-based and restorative therapies. These cells have high flexibility and can differentiate into several types of cells in vitro. This article will investigate the effects and possible mechanisms and signaling pathways of adipose tissue-derived mesenchymal stem cells in patients with refractory peptic ulcers.
\end{abstract}

Keywords: Refractory peptic ulcer, Peptic ulcer, Mesenchymal stem cells, Adipose tissue, Cell therapy

\section{Introduction}

Upper gastrointestinal tract consists of the mouth, throat, esophagus, stomach, and duodenum. The stomach is the muscular, bean-shaped part of the gastrointestinal tract meant for the initial digestion of food and infectivity [1]. The stomach eliminates incoming pathogens by secreting acidic fluids and facilitates the denaturation of proteins and the absorption of metals. Salivary amylase and peptidases secreted by corpus glands digest carbohydrates and proteins [2]. The stomach breaks down food into smaller pieces to prepare it for absorption in the small intestine. The duodenum is a $25-38 \mathrm{~cm}(10-15$ inch) C-shaped structure adjacent to the stomach [3]. The incidence of

*Correspondence: a.vaezi@abzums.ac.ir

${ }^{4}$ Department of Internal Medicine, Alborz University of Medical Science, Karaj, Iran

Full list of author information is available at the end of the article ulcers increases with age for duodenal ulcers (DU) and gastric ulcers (GU). DUs, especially in men, occur two decades earlier than GU [4]. The prevalence of GU disease in the general population is estimated at 5-10\% [5], and its incidence is $0.1-0.3 \%$ per year [6]. Ulcer healing is a complex, multi-step process involving inflammation, cell proliferation, re-epithelialization, angiogenesis, and other mechanisms controlled by cytokines $[7,8]$. It has also been suggested that circulating ancestral cells, including bone marrow-derived stem cells, play a crucial role in healing mucous membrane ulcers, connective tissue regeneration, and neovascularization [9].

\section{Peptic ulcer}

Peptic ulcer is caused by a defect in duodenal or gastric mucosa, and in fact, sustained activity of acid and pepsin leads to damage to the mucosa and ultimately to ulcers [10]. The outcome of peptic ulcer ranges from healing

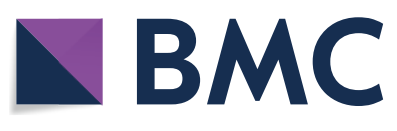

(c) The Author(s) 2021. Open Access This article is licensed under a Creative Commons Attribution 4.0 International License, which permits use, sharing, adaptation, distribution and reproduction in any medium or format, as long as you give appropriate credit to the original author(s) and the source, provide a link to the Creative Commons licence, and indicate if changes were made. The images or other third party material in this article are included in the article's Creative Commons licence, unless indicated otherwise in a credit line to the material. If material is not included in the article's Creative Commons licence and your intended use is not permitted by statutory regulation or exceeds the permitted use, you will need to obtain permission directly from the copyright holder. To view a copy of this licence, visit http://creativecommons.org/licenses/by/4.0/. The Creative Commons Public Domain Dedication waiver (http://creativeco mmons.org/publicdomain/zero/1.0/) applies to the data made available in this article, unless otherwise stated in a credit line to the data. 
without intervention to complications such as bleeding and perforation. In the past, an acidic environment and factors such as diet or stress were thought to account for most cases of peptic ulcer; however, the discovery of Helicobacter pylori infection and widespread use of nonsteroidal anti-inflammatory drugs (NSAIDs) has changed this perception [5]. The incidence of ulcers has increased significantly due to extensive and long-term use of NSAIDs [11]. Therapeutic measures include medical and surgical treatments. Ulcers caused by aspirin consumption might require medical intervention and sometimes surgery. Medications involve the inhibition of gastric acid secretion by H2-receptor antagonists or proton pump inhibitors (PPI), as well as antibiotics to eliminate $H$. pylori [12]. An esophageal ulcer is an injury to the margin of the esophageal mucosa. This mucosal damage to the esophagus is often caused by gastroesophageal reflux disease or severe esophagitis caused by other factors [13, 14]. Inflammatory infections of the esophagus commonly seen in immunocompromised individuals include Candida, Herpes simplex, and Cytomegalovirus [15].

Radiotherapy is used to treat half of all cancer patients and plays a vital role in cancer treatment. The intestine is one of the most critical tissues damaged during radiation therapy of abdominal and pelvic tumors. Radiation enteropathy is generally classified into acute and chronic. Acute enteropathy occurs within 3 months after radiotherapy and chronic enteropathy for more than 3 months [16]. Acute damage from radiotherapy mainly involves rapidly proliferating cells, for example, exposing the epithelial surfaces of the skin or gastrointestinal tract. Radiation damages stem cells, and tissues are destroyed when they have an insufficient replacement with stem cells due to radiation damage [17]. Furthermore, this causes the protective barriers to disappear, especially in tissues such as the skin, oral mucosa, and gastrointestinal tract, mainly 1-5 years after the end of radiotherapy. After a while, compensatory hyperplasia in the stem cells helps the tissue to heal. When an acute injury does not fully heal, a delayed phase occurs with late consequences [18]. Such changes occur in the combination of chemotherapy and radiotherapy. The delayed effects are due to the interaction of different cytokines and cellular adaptive processes. Vascular damage leads to increased permeability and release of vascular cytokines, TGFbeta and fibrin, which cause collagen deposition [19, 20]. Chronic complications include chronic diarrhea, malabsorption, recurrent ileus attacks or obstruction, proliferative mucosal telangiectasia, or ulceration [21]. Excessive cell loss may perpetuate cytokine storms and irregular cell interactions. The type of cytokines released depends on the tissue type and is responsible for the differential response of tissues to radiation $[19,22]$. Treatment strategies for chronic enteropathies include oral anti-inflammatory drugs, analgesics, stool softeners, steroid enemas, blood transfusions in the presence of bleeding, and mechanical dilatation of injuries. For severe or refractory complications, hyperbaric oxygenation, endoscopic intervention, or surgery involving colostomy may be required [23].

Although radiation therapy is effective in managing malignant tumors of the abdomen and pelvis, radiation entropy is inevitable. The disease leads to resistant lesions such as intestinal ischemia, mucositis, refractory ulcers, necrosis, or even perforation, negatively impacting the patient's quality of life [24]. A peptic ulcer is a common health problem worldwide and faces many challenges in treating resistant ulcers. In this review article, we discuss refractory peptic ulcer disease and new alternative therapies.

\section{Refractory peptic ulcer}

A refractory peptic ulcer (RPU) is an endoscopically confirmed ulcer larger than $5 \mathrm{~mm}$ that does not heal after 8-12 weeks of treatment with a proton pump inhibitor. Persistent Helicobacter pylori can lead to refractory peptic ulcers [25] because this infection might not receive enough attention at first, Helicobacter pylori test is falsely negative, or the eradication treatment of this bacterium is unsuccessful [26]. In some patients, persistent ulcers may function as a severe inflammatory response, dense ulcers, or decreased mucosal blood flow impairs angiogenesis and tissue repair [27]. Peptic ulcer disease (PUD) is a significant cause for upper gastrointestinal bleeding (UGI), and Helicobacter pylori infection is the main causative factor of PUD. Resistant peptic ulcer disease (RPU) appears as persistent and recurrent bleeding or GI-related complications such as perforation, stenosis, and obstruction [28]. Table 1 lists various factors leading to the development of RPU [28-30]. Studies have shown that the size of an ulcer affects the healing rate so that larger ulcers need more time to heal [31]. Another condition disrupting the healing process of ulcers is the presence of fibrosis in larger ulcers [32]. In patients with refractory gastric ulcers, studying the underlying cause and risk factors in this disease is of great importance.

The stomach and duodenum are sometimes damaged during radiotherapy for hepatocellular, biliary-pancreatic cancers, or lymphoma [33]. Radiation-refractory ulcers are challenging to treat and usually do not heal with conventional therapy for ulcers. Extracorporeal radiation and transarterial chemoembolization using radioisotopes are two treatments that can create refractory peptic ulcers [34]. 
Table 1 Etiology of refractory peptic ulcers

\begin{tabular}{lll}
\hline $\begin{array}{l}\text { The most common causes of refractory peptic } \\
\text { ulcers }\end{array}$ & $\begin{array}{l}\text { Less common causes of refractory peptic } \\
\text { ulcers }\end{array}$ & Rare causes of refractory peptic ulcers \\
\hline Persistent H. pylori infection & Radiation therapy & Malignancy (gastric/lung cancer, lymphomas) \\
Continued NSAID Use & Crack cocaine use & Gastric acid hypersecretion (retained antrum \\
Medications & Mesenteric ischemia & syndrome and Zollinger-Ellison syndrome) \\
Aspirin & & Other viral and bacterial infections (TB, Syphilis, \\
& & CMV, HPV) \\
& & Sarcoidosis \\
& & Behçet disease \\
& & Polyarteritis nodosa \\
& Crohn disease \\
& & Vasculitides \\
& Smoking \\
& Stress (acute illness, burns, head injury) \\
& Chemotherapy
\end{tabular}

\section{Pathophysiology}

H. pylori infection and the consumption of NSAIDs or aspirin are the main risk factors for gastric and duodenal ulcers $[6,35,36]$. The mechanism by which $H$. pylori causes various types of lesions in gastrointestinal mucosa is not fully understood [5]. Inflammation associated with $H$. pylori infection can lead to hypochlorhydria or hyperchlorhydria and cause a specific peptic ulcer [37]. In $5-10 \%$ of patients with $H$. pylori, somatostatin decreases and gastrin increases [38]. This process is followed by increasing secretion of histamine, which leads to enhanced release of pepsin or acid from chief and parietal cells of the stomach and eventually to development of peptic ulcers [39]. NSAIDs damage the gastrointestinal mucosa through systemic and local mechanisms, but systemic inhibition of cyclooxygenase-1 (COX-1) derived prostaglandins is considered significant. Decreased prostaglandin levels are associated with reduced mucus and bicarbonate secretion, inhibiting cell proliferation and diminishes mucosal blood flow, all of which are essential for maintaining mucosal integrity [40]. Prostaglandins derived from both COX-1 and COX-2 inducible enzymes appear to play a significant role in mucosal repair [41]. The inhibition of prostaglandins, vascular damage, and local effects are involved in the pathogenesis of ulcers initiated by NSAIDs [5]. Aspirin can also cause mucosal damage through local and systemic mechanisms, albeit slightly [42].

Excessive return of acid and pepsin leads to necrosis of the superficial layers of the esophageal mucosa and causes erosion and esophageal ulcers due to gastroesophageal reflux disease. The extent of damage to the esophageal mucosa is determined by prolonged exposure to bile salts and gastric acids. Extra factors contributing to the formation of esophageal ulcers include decreased gastric acid removal from the esophagus and reduced contraction of the lower esophageal sphincter. Esophageal ulcers due to chronic gastroesophageal reflux disease are associated with decreased rest of the upper esophageal sphincter, which can accelerate laryngeal symptoms such as clearing throat, chronic cough, and sore throat [15]. Other esophageal ulcers are caused by using pills that have a low $\mathrm{PH}$. These pills destroy the protective mucosal barrier and cause esophageal ulcers [43, 44].

\section{Mesenchymal stem cells and ulcer healing}

Mesenchymal stem cells (MSC) are multipotent progenitor cells with proliferation and self-regeneration capacity [45]. To standardize MSC, the International Association of Cell Therapy (ISCT) proposes the following criteria: the ability to adhere to plastic and having a fibroblastoid phenotype, expression of CD105, CD73, and CD90 markers, non-expression of CD45, CD34, CD14, CD19, and HLA-DR surface molecules, the capacity to differentiate into cartilage, adipocyte, and bone lineages. Other features of these cells are low immunogenicity and subsequent use at the clinic in autologous and allogeneic forms [46]. MSCs, like ready soldiers, are present in all types of adult tissues, including bone marrow, adipose, skin, placenta, and heart [47]. These cells secrete various inflammatory factors and recruit inflammatory cells at the time of damage, quickly migrating through blood vessels and implanting via their surface receptors with stromal cellderived factor (SDF-1) released from the affected area to control the immune system by secreting various factors $[48,49]$.

On the other hand, these cells participate in tissue repair to differentiate into various types of tissues. In addition, these cells likely play an essential role in repairing the lesion by affecting the stem cells residing in each tissue and inducing their proliferation [50]. Due to their low immunogenicity and immune-regulating properties, MSCs have therapeutic effects in various inflammatory diseases. They can implant at the injury site, limiting 
inflammation through the secretion of cytokines through the expression of growth factor, stimulating the healing of the ulcer, modifying host immune responses by secreting regulatory proteins and anti-apoptotic agents to alter the patient's immune system [51].

\section{Adipose-derived mesenchymal stem cells (AD-MSC)}

ADMSCs are isolated from adipose tissue using liposuction through washing, enzymatic digestion by collagenase, centrifugation, and the isolation of ADMSCs is less invasive and more accessible than BM-MSCs [52]. ADMSCs stimulate regulatory T-cells (Tregs) and suppress Th1, Th2, and Th17 cells by increasing immunemodulatory factors such as IL-10, TGF- $\beta$, and IDO (Indoleamine 2, 3-dioxygenase). ADMSCs also downregulate inflammatory factors such as IL-4, IL-12, IL-17, tumor necrosis factor (TNF- $\alpha$ ), interferon (IFN- $\gamma$, t-bet, CD80, CD83, and CD86) [53, 54]. ADMSCs express CD-106 marker (also known as VCAM-1), which plays a role in cellular migration at a lower level than BM-MSCs do [55]. ADMSC secrete a variety of factors, including IL-6, IL-8, interleukin-1 alpha receptor (IL-1R $\alpha$ ), granulocyte colony-stimulating factor (G-CSF), granulocyte-macrophage colony-stimulating factor (GM-CSF), transforming growth factor (TGF- $\beta$ ), prostaglandin E2 (PGE2), monocyte chemotactic protein 1 (MCP-1), nerve growth factor (NGF), and hepatocyte growth factor (HGF) [56-58].

\section{Therapeutic approaches for RPU and AD-MSC advantages}

Therapeutic strategies for bleeding complications include endoscopic treatment, surgery, and transcatheter angiolysis embolization [28]. Medical regimens for identification and eradication of $H$. pylori and widespread use of proton pump inhibitor therapy (PPI) to suppress gastric acid secretion have led to successful management of PUD in the vast majority of patients $[59,60]$. PPI is the most potent drug for the treatment of stomach ulcers. However, some gastric ulcers do not heal even with PPI treatment [29]. In these patients, anti-secretory therapies such as omeprazole are used, especially in cases of PPI resistance, which has been somewhat effective [61]. However, PPIs are the preferred treatment for patients with refractory ulcers. RPU ulcers are those gastric ulcers that do not heal entirely despite $8-12$ weeks of anti-secretory drug treatment [29]. Competitive potassium acid inhibitors are also valuable for preventing NSAID-related ulcer disease, but there is no adequate access to these inhibitors [62]. Surgery is rarely performed and is only used for gastric ulcers that do not heal after treatment with anti-secretory factors and PPI for 24 weeks and are associated with conditions such as drug interactions, NSAID history, and H. pylori infection [63]. Recently, indications for gastric ulcer surgery include bleeding, perforation, obstruction, intractable disease, and suspected malignancy [64]. Cell-based therapies in restorative medicine have been promising for many diseases, and MSCs have been widely used in basic laboratory research up to clinical trials $[65,66]$. MSCs can be effective as alternative therapies for patients due to their self-renewal, proliferation, and differentiation [67].

\section{Mechanism of adipose-derived mesenchymal stem cells on peptic ulcer healing}

Peptic ulcer healing involves improving inflammation, cell migration and epithelial regeneration (re-epithelialization), neovascularization, glandular and matrix regeneration [9]. The process of MSCs implantation includes a cascade of interactions, the main stage of which is rolling. In this process, circulating MSCs attach to endothelial cells by adhesion molecules and then transmigrate to the damaged area [68]. Because radiotherapy-refractory peptic ulcers cause excessive cell loss and irreversible tissue damage $[22,69]$, an alternative cellular source to fill this gap and reconstruct tissue can benefit the patient. For this purpose, stem cells are a suitable source for repair tissue. These cell-cell contacts can be effectively improved. Mesenchymal stem cells exert their protective effect on irradiated tissue through essential mechanisms [69]. In hematopoiesis induced by mesenchymal stem cells, the cytokine storage lost after radiation, such as SDF1, GMCSF, and IL- 6 is compensated by these stem cells [70]. Another mechanism is the prevention of apoptosis of hematopoietic cells and repairing bone marrow damaged by radiation [71, 72]. Radiation usually kills high-proliferation cells, including progenitor cells, and induces many changes in tissue microenvironment and endothelial cells, including apoptosis, increased permeability, and basement membrane detachment [73, 74]. In this case, the stem cells migrate to the area damaged by the radiation and secrete important cytokines and antioxidants that activate the proliferative and regenerative processes $[75,76]$. One study showed that adiposederived mesenchymal stem cells play an essential role in wound healing following radiotherapy by increasing TIMPs and TIMP1 [77].

Several studies have shown that SDF-1 increases at the site of injury and acts as a strong adsorbent to implant MSC cells at that site [78]. Adipose-derived mesenchymal stem cells express CXCR4 and therefore migrate to the site of injury via SDF-1/CXCR4 [79, 80]. In addition, MSCs expressing the VLA-4 marker can perform the implantation process by interacting with VCAM-1 expressed on blood vessels $[79,81]$. ADSCs are suitable for healing ulcers due to their ability to differentiate into several cell types, including endothelial cells and 
secretion of angiogenic and anti-apoptotic factors [82]. In ulcer healing, adipose tissue-derived stem cells release VEGF, TGF- $\beta$, FGF, and HGF growth factors and have beneficial effects in improving vasculogenesis and inhibiting inflammation [83-85]. Mesenchymal stem cells reduce inflammation in ulcers via secreting TGF- $\beta$ [86]. They can accelerate the regeneration of colitis in laboratory models by producing hepatic growth factor (HGF), vascular endothelial growth factor (VEGF), and adiponectin [87]. VEGF secretion by ADSCs under normal and abnormal conditions has been reported as a factor for ADSC-mediated angiogenesis [88]. COX-PGE2 plays an essential role in maintaining the integrity of gastric mucosa [89]. The most likely underlying mechanism for the migration of stem cells injected through peripheral blood into damaged gastric tissue is the release of angiogenic growth factors such as VEGF and PGE2. PGE2 is an important protective factor for gastric mucosa against ulcers, healing ulcers by improving blood flow and stimulating VEGF secretion. ADSCs induce angiogenesis and heal gastric ulcers due to having VEGF and PGE2 receptors, respectively, improving blood flow and stimulating further VEGF secretion [87]. The ERK1/2MAPK and PI3K/AKT signaling pathways are critical for cell survival, migration, and angiogenesis [90, 91]. Studies on PUD show that following injection of ADMSCs, AKT, and ERK phosphorylation increase and activate ERK1/2-MAPK and PI3K/AKT signaling pathways [89]. In gastric ulcer healing, the ERK1/2-MAPK pathway is critical for angiogenesis and re-epithelialization [90, 92]. Mesenchymal stem cells can regulate the immune response, adjusting the function of regulatory T-cells by suppressing T-cell proliferation and secretion of cytotoxic cytokines. They also inhibit the proliferation and maturation of B-cells, antigen presentation by dendritic cells, and the activation of natural killer cells by IL-2 [93]. In an environment where the IFN- $\gamma$ level is elevated, MSCs enhance immunomodulatory activity by producing inflammatory inhibitors such as IDO, H6 factor, PGE2 , TGF- $\beta$, and HGF- 8 [94]. The schematic mechanism of ADMSC cells in RPU is shown in Fig. 1.

Mesenchymal stem cells have been used in several animal models of gastric ulcer, some of which we will review in this study. In a study by Xianfeng et al.,

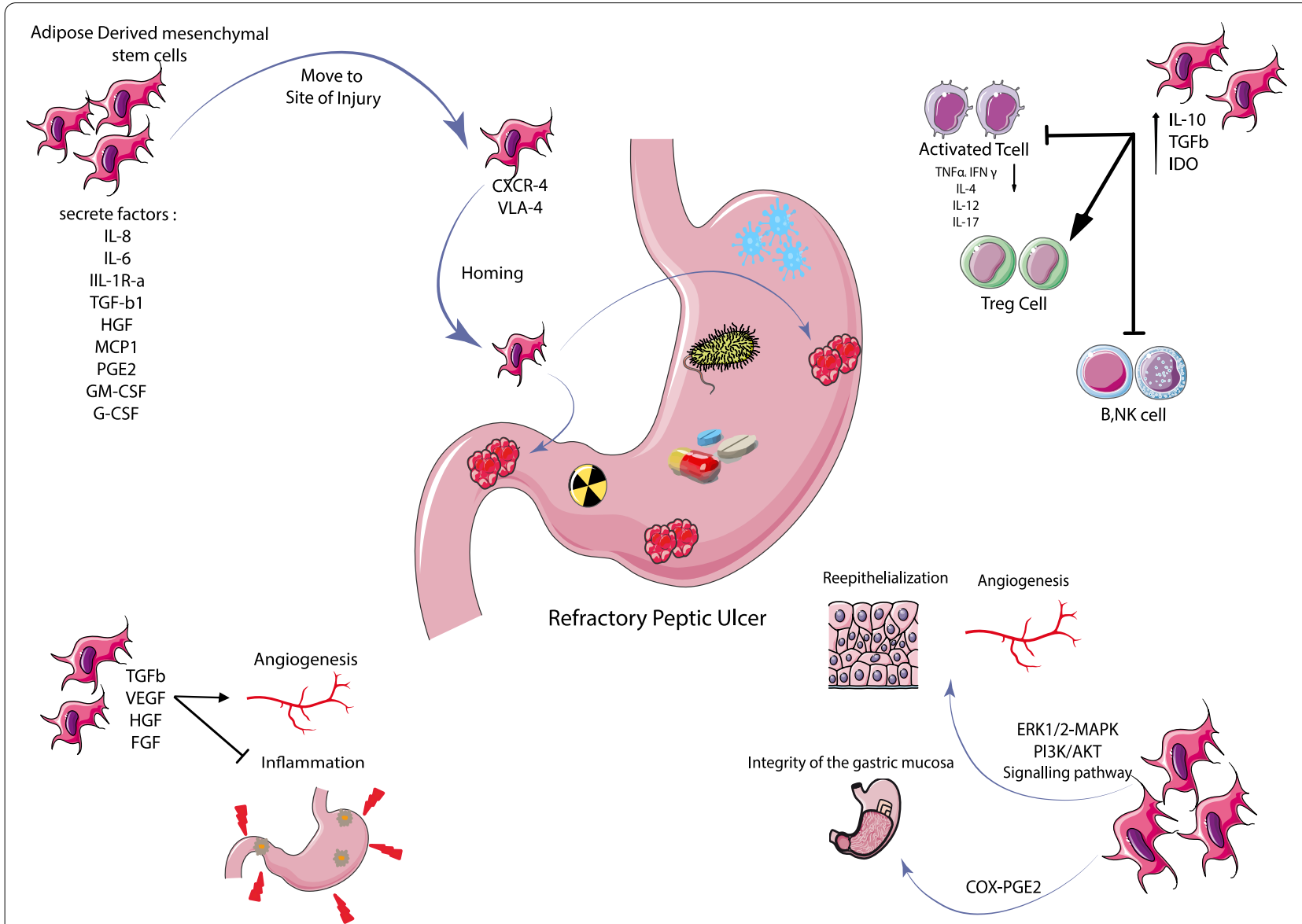

Fig. 1 Mechanism of ADMSC cells in RPU 
ADMSCs were used in an NSAID-induced peptic ulcer in a pig model. This research stated that endoscopic submucosal injection of ADMSC is a promising method in healing NSAID-related gastric ulcers and that the paracrine effects released by mesenchymal stem cells play a crucial role in this process [89]. In another study by L. Liu and colleagues, MSCs were injected locally into a mouse model with gastric perforation. This investigation showed that MSCs facilitate the improvement of gastric perforation by re-epithelialization, granulation tissue regeneration, TGF- $\beta 1$ secretion, and inhibition of inflammation [95]. Another study in an indomethacin-induced gastric ulcer model showed that ADMSCs improved the histopathology of gastric tissue. In this research, $3 \times 106$ ADMSCs were injected through peripheral blood, and it was shown that stem cell injection reduced pathological changes in gastric ulcer morphology and restored gastric prostaglandin E2 levels to normal. Mesenchymal stem cells also increase VEGF levels to higher than usual, leading to an accelerated healing process [87]. In a study by Chang et al., BMMSCs were labeled with CFDA SE, and $1 \times 107$ cells were injected into a mouse model with the damaged gastric mucosa. Forty-eight and seventy-two hours after transplantation, BMMSC was present in the damaged gastric mucosa. After histopathological examination and evaluation of gastric ulcer index, they observed a significant improvement in gastric ulcer [96].

Yujiro and colleagues injected $1 \times 10^{7}$ BM-MSC labeled with PKH67 locally into the stomach wall around the ulcer and found that MSC transplantation accelerated the healing of gastric ulcers by inducing angiogenesis in the gastric mucosa via secreting VEGF factor. The beneficial effects of these cells may be due to their differentiation into gastric interstitial cells and their ability to secrete the factors involved in angiogenesis [97]. In a study by Alazzouni et al., the antiinflammatory effect of bone marrow mesenchymal stem cells (BM-MSCs) on piroxicam-induced gastric ulcers in rats was compared with anti-inflammatory drugs such as Pantoloc, which is a proton pump inhibitor. This study showed that BM-MSCs have a therapeutic capacity as anti-ulcers due to high antioxidant activity [98]. In another research, ADMSCs were used in aspirin-induced gastric ulcers. At $72 \mathrm{~h}$ after $\mathrm{AD}$ MSC transplantation, there was the complete repair of the gastric fundus glands with a significant reduction in inflammatory cell infiltration. This study showed that AD-MSCs are easily isolated and removed from adipose tissue, multiplying rapidly in culture medium to play a role in the healing process of gastric ulcers [99].

\section{Conclusion}

When RPU occurs in a patient, it is essential to have a systematic approach to diagnosis and treatment, and several treatments are available to patients. Recently, concerns have been raised about the risk of long-term use of proton pump inhibitors. For RPU-refractory and gastric ulcers, surgery is sometimes performed to reduce gastric acid secretion to heal gastric ulcers. It is unclear whether medical or surgical management is better for people with persistent or recurrent gastric ulcers. Therefore, stem cell-based therapy can be helpful in these patients. These findings are significant not only pathophysiologically but also clinically because chronic gastrointestinal ulcers are detectable and endoscopic. Therefore, MSC transplantation can be considered a new therapeutic strategy for resistant gastrointestinal ulcers. Moreover, radiation enteropathy is a frequent complication in patients with abdominal malignancy, but no treatment has yet been identified. Mesenchymal stem cell therapy may be a valuable treatment option for radiation-resistant ulcers because the loss of stem cell tissue explains the incurability of these diseases.

\section{Abbreviations \\ MSCs: Mesenchymal stem cells; ASC: Adipose-derived mesenchymal stromal stem cells; AD-MSC: Adipose-derived mesenchymal stem cells; BM-MSCs: Mone marrow mesenchymal stem cells; DU: Duodenal ulcers; GU: Gastric ulcers; NSAIDs: Nonsteroidal anti-inflammatory drugs; GU: Gastric ulcer; PPI: Proton pump inhibitors; RPU: Refractory peptic ulcer; PUD: Peptic ulcer disease; UGI: Upper gastrointestinal bleeding; COX-1: Cyclooxygenase-1: ISCT: International Society for Cell Therapy; VEGF: Vascular endothelial growth factor; VCAM-1: Vascular cell adhesion molecule 1; PGE2: Prostaglandin E2; bFGF: Basic fibroblast growth factor; NGF: Nerve growth factor; TGF-b1: \\ Transforming growth beta-1; IFN- $\gamma$ : Interferon- $;$; TNF-a: Tumor necrosis factor a; IL-1a: Interleukin-1 alpha; SDF-1: Stromal cell-derived factor 1; MCP 1/CCL2: Monocyte chemoattractant protein-1; HGF: Hepatocyte growth factor; G-CSF: Granulocyte-colony stimulating factor; GM-CSF: Granulocyte-macrophage colony stimulating factor; Tregs: Regulatory T-cells; VLA-4: Very late antigen 4.}

\section{Acknowledgements}

Not applicable.

\section{Authors' contributions}

MS and AV contributed to the concept of the review. MS, AV, MM, AS, MK and IS were responsible for the reference selection and writing of the manuscript. MS is responsible for designing the figure of the article. MS contributed to the critical review of the manuscript. All authors read and approved the final manuscript.

\section{Funding}

This work was supported by the Tehran University of Medical Sciences.

Availability of data and materials

Not applicable.

\section{Declarations}

Ethics approval and consent to participate

Not applicable. 


\section{Consent for publication \\ Not applicable.}

\section{Competing interests}

The authors declare that they have no competing interests.

\begin{abstract}
Author details
${ }^{1}$ Department of Applied Cell Sciences, School of Advanced Technologies in Medicine, Tehran University of Medical Sciences, Tehran, Iran. ${ }^{2}$ Gastroenterology and Hepatology, Liver and Pancreatobiliary Diseases Research Center, Digestive Disease Research Institute, Tehran University of Medical Sciences, Tehran, Iran. ${ }^{3}$ Department of Laboratory Sciences, Borujerd Branch, Islamic Azad University, Borujerd, Iran. ${ }^{4}$ Department of Internal Medicine, Alborz University of Medical Science, Karaj, Iran.
\end{abstract}

Received: 25 June 2021 Accepted: 4 September 2021

Published online: 26 September 2021

\section{References}

1. Grützner P. Ein beitrag zum mechanismus der magenverdauung. Archiv für die gesamte Physiologie des Menschen und der Tiere. 1905:106(10):463-522

2. Koelz H. Gastric acid in vertebrates. Scand J Gastroenterol. 1992;27(Sup193):2-6.

3. Drake R, Vogl AW, Mitchell AW. Gray's anatomy for students E-book. Amsterdam: Elsevier Health Sciences; 2009.

4. Sonnenberg A. Temporal trends and geographical variations of peptic ulcer disease. Aliment Pharmacol Ther. 1995;9:3-12.

5. Lanas A, Chan FK. Peptic ulcer disease. Lancet. 2017;390(10094):613-24

6. Del Valle J. Peptic ulcer disease and related disorders. In: Harrisons principles of internal medicine, vol 16, No. 2; 2005. p. 1746.

7. Watanabe S, Arimura Y, Nagaishi K, Isshiki H, Onodera K, Nasuno M, et al. Conditioned mesenchymal stem cells produce pleiotropic gut trophic factors. J Gastroenterol. 2014;49(2):270-82.

8. Tarnawski AS. Cellular and molecular mechanisms of gastrointestinal ulcer healing. Dig Dis Sci. 2005;50(1):S24-33.

9. Tarnawski AS, Ahluwalia A. Molecular mechanisms of epithelial regeneration and neovascularization during healing of gastric and esophageal ulcers. Curr Med Chem. 2012;19(1):16-27.

10. Peery AF, Dellon ES, Lund J, Crockett SD, McGowan CE, Bulsiewicz WJ, et al. Burden of gastrointestinal disease in the United States: 2012 update. Gastroenterology. 2012;143(5):1179-87.e3.

11. Cai S, García Rodríguez L, Masso-Gonzalez E, Hernandez-Diaz S. Uncomplicated peptic ulcer in the UK: trends from 1997 to 2005. Aliment Pharmacol Ther. 2009;30(10):1039-48.

12. Kang JM, Kim N, Kim B, Kim J-H, Lee B-Y, Park JH, et al. Enhancement of gastric ulcer healing and angiogenesis by cochinchina Momordica seed extract in rats. J Korean Med Sci. 2010;25(6):875.

13. Sasaki S, Nishikawa J, Goto A, Sakaida I. Dabigatran-induced esophageal ulcer at a natural constriction. Intern Med. 2019;58(5):757-8.

14 Maesaka K, Tsujii Y, Shinzaki S, Yoshii S, Hayashi Y, lijima H, et al. Successful treatment of drug-induced esophageal ulcer in a patient with chronic heart failure: a case report. Medicine. 2018;97(48):e13380.

15. Chiejina M, Samant H. Esophageal ulcer. In: StatPearls. Treasure Island (FL): StatPearls Publishing: 2020.

16. Hauer-Jensen M, Denham JW, Andreyev HJN. Radiation enteropathypathogenesis, treatment and prevention. Nat Rev Gastroenterol Hepatol. 2014;11(8):470-9.

17. Dewey W, Furman S, Miller H. Comparison of lethality and chromosomal damage induced by X-rays in synchronized Chinese hamster cells in vitro. Radiat Res. 1970;43(3):561-81.

18. Majeed H, Gupta V. Adverse effects of radiation therapy. StatPearls. 2020.

19. Rubin P, Johnston CJ, Williams JP, McDonald S, Finkelstein JN. A perpetual cascade of cytokines postirradiation leads to pulmonary fibrosis. Int J Radiat Oncol Biol Phys. 1995;33(1):99-109.

20. Barcellos-Hoff MH. How do tissues respond to damage at the cellular level? The role of cytokines in irradiated tissues. Radiat Res. 1998;150(5s):S109-20.
21. O'Brien PC. Radiation injury of the rectum. Radiother Oncol. 2001;60(1):1-14.

22. Coderre JA, Morris GM, Micca PL, Hopewell JW, Verhagen I, Kleiboer $\mathrm{BJ}$, et al. Late effects of radiation on the central nervous system: role of vascular endothelial damage and glial stem cell survival. Radiat Res. 2006;166(3):495-503.

23. Pavi J, Denekamp J, Letschert J. LENT-SOMA scales for all anatomic sites. Int J Radiat Oncol Biol Phys. 1995;31(5):1049-91.

24 Chang P, Qu Y, Wang J, Dong L. The potential of mesenchymal stem cells in the management of radiation enteropathy. Cell Death Dis. 2015;6(8):e1840.

25. Soybel DI. Overview of complications of peptic ulcer disease. https:// www.uptodate.com/contents/overview-of-complications-of-pepticulcer-disease.

26. Lanas A, Remacha B, Sáinz R, Hirschowitz Bl. Study of outcome after targeted intervention for peptic ulcer resistant to acid suppression therapy. Am J Gastroenterol. 2000;95(2):513-9.

27. Shih S-C, Tseng K-W, Lin S-C, Kao C-R, Chou S-Y, Wang H-Y, et al. Expression patterns of transforming growth factor-beta and its receptors in gastric mucosa of patients with refractory gastric ulcer. World J Gastroenterol WJG. 2005;11(1):136

28. Napolitano L. Refractory peptic ulcer disease. Gastroenterol Clin. 2009;38(2):267-88

29. Kim HU. Diagnostic and treatment approaches for refractory peptic ulcers. Clin Endosc. 2015;48(4):285

30. Rothermel CE, Edwards AL. Challenges in the management of peptic ulcer disease. JCOM. 2020;27(6):281-8. https://doi.org/10.12788/jcom. 002.

31. Steigmann F, Shulman B. The time of healing of gastric ulcers: implications as to therapy. Gastroenterology. 1952;20(1):20-6.

32. Reynolds JC, Schoen RE, Maislin G, Zangari GG. Risk factors for delayed healing of duodenal ulcers treated with famotidine and ranitidine. Am J Gastroenterol. 1994:89(4):571-80.

33. Zeng C, Luo S, Lv N, Chen Y. Refractory peptic ulceration following radiation therapy in primary gastric lymphoma: a report of two cases. Oncol Lett. 2015;9(1):63-6.

34. Yim SY, Kim JD, Jung JY, Kim CH, Seo YS, Yim HJ, et al. Gastrectomy for the treatment of refractory gastric ulceration after radioembolization with 90Y microspheres. Clin Mol Hepatol. 2014;20(3):300.

35. Zhang B-B, Li Y, Liu X-Q, Wang P-J, Yang B, Bian D-L. Association between vacA genotypes and the risk of duodenal ulcer: a meta-analysis. Mol Biol Rep. 2014:41(11):7241-54.

36. Huang J-Q, Sridhar S, Hunt RH. Role of Helicobacter pylori infection and non-steroidal anti-inflammatory drugs in peptic-ulcer disease: a metaanalysis. Lancet. 2002;359(9300):14-22.

37. Meyer-Rosberg K, Scott DR, Rex D, Melchers K, Sachs G. The effect of environmental $\mathrm{pH}$ on the proton motive force of Helicobacter pylori. Gastroenterology. 1996;111(4):886-900.

38. El-Omar EM, Oien K, El-Nujumi A, Gillen D, Wirz A, Dahill S, et al. Helicobacter pylori infection and chronic gastric acid hyposecretion. Gastroenterology. 1997:113(1):15-24.

39. Moss SF, Calam J, Legon S, Bishop A, Polak J. Effect of Helicobacter pylori on gastric somatostatin in duodenal ulcer disease. Lancet. 1992;340(8825):930-2.

40. Silverstein FE, Graham DY, Senior JR, Davies HW, Struthers BJ, Bittman RM, et al. Misoprostol reduces serious gastrointestinal complications in patients with rheumatoid arthritis receiving nonsteroidal anti-inflammatory drugs: a randomized, double-blind, placebo-controlled trial. Ann Intern Med. 1995;123(4):241-9.

41. Perini RF, Ma L, Wallace JL. Mucosal repair and COX-2 inhibition. Curr Pharm Des. 2003;9(27):2207-11.

42. Sostres C, Lanas A. Gastrointestinal effects of aspirin. Nat Rev Gastroenterol Hepatol. 2011;8(7):385.

43. Matsumoto Y, Kaneshiro T, Hijioka N, Nodera M, Yamada S, Kamioka $M$, et al. Predicting factors of transmural thermal injury after cryoballoon pulmonary vein isolation. J Interv Card Electrophysiol. 2019;54(2):101-8

44 Misiak P, Jabłoński S, Piskorz Ł, Dorożała L, Terlecki A, Wcisło S. Oesophageal perforation-therapeutic and diagnostics challenge. Retrospective, single-center case report analysis (2009-2015). Polish J Surg. 2017;89:1-4. 
45. Chamberlain G, Fox J, Ashton B, Middleton J. Concise review: mesenchymal stem cells: their phenotype, differentiation capacity, immunological features, and potential for homing. Stem Cells. 2007;25(11):2739-49.

46. Djouad F, Bouffi C, Ghannam S, Noël D, Jorgensen C. Mesenchymal stem cells: innovative therapeutic tools for rheumatic diseases. Nat Rev Rheumatol. 2009;5(7):392-9.

47. Horwitz E, Keating A. The Nonhematopoietic Mesenchymal Stem Cell Committee Workshop. Nonhematopoietic mesenchymal stem cells: what are they? Cytotherapy. 2000;2(5):387-8.

48. Xiao Ling K, Peng L, Jian Feng Z, Wei C, Wei Yan Y, Nan S, et al. Stromal derived factor-1/CXCR4 axis involved in bone marrow mesenchymal stem cells recruitment to injured liver. Stem cells Int. 2016;2016:8906945.

49. Pillarisetti K, Gupta SK. Cloning and relative expression analysis of rat stromal cell derived factor-1 (SDF-1): SDF-1 a mRNA is selectively induced in rat model of myocardial infarction. Inflammation. 2001;25(5):293-300.

50. Saleh M, Taher M, Sohrabpour AA, Vaezi AA, Nasiri Toosi M, Kavianpour M, et al. Perspective of placenta derived mesenchymal stem cells in acute liver failure. Cell Biosci. 2020;10:1-11.

51. Mehrabani D, Khajehahmadi Z, Tajik P, Tamadon A, Rahmanifar F, Ashraf $M$, et al. Regenerative effect of bone marrow-derived mesenchymal stem cells in thioacetamide-induced liver fibrosis of rats. Arch Razi Inst. 2019;74(3):279-86.

52. Fraser JK, Wulur I, Alfonso Z, Hedrick MH. Fat tissue: an underappreciated source of stem cells for biotechnology. Trends Biotechnol. 2006;24(4):150-4.

53. Mohammadzadeh A, Pourfathollah AA, Shahrokhi S, Hashemi SM, Moradi SLA, Soleimani M. Immunomodulatory effects of adipose-derived mesenchymal stem cells on the gene expression of major transcription factors of T cell subsets. Int Immunopharmacol. 2014;20(2):316-21.

54. Peng W, Gao T, Yang Z-I, Zhang S-C, Ren M-I, Wang Z-G, et al. Adiposederived stem cells induced dendritic cells undergo tolerance and inhibit Th1 polarization. Cell Immunol. 2012;278(1-2):152-7.

55. Pachón-Peña G, Yu G, Tucker A, Wu X, Vendrell J, Bunnell B, et al. Stromal stem cells from adipose tissue and bone marrow of age-matched female donors display distinct immunophenotypic profiles. J Cell Physiol. 2011;226(3):843-51.

56. Banas A, Teratani T, Yamamoto Y, Tokuhara M, Takeshita F, Osaki M, et al. IFATS collection: in vivo therapeutic potential of human adipose tissue mesenchymal stem cells after transplantation into mice with liver injury. Stem cells. 2008;26(10):2705-12.

57. Hao T, Chen J, Zhi S, Zhang Q, Chen G, Yu F. Comparison of bone marrowversus adipose tissue-derived mesenchymal stem cells for attenuating liver fibrosis. Exp Therap Med. 2017;14(6):5956-64.

58. Ma S, Xie N, Li W, Yuan B, Shi Y, Wang Y. Immunobiology of mesenchymal stem cells. Cell Death Differ. 2014;21(2):216-25.

59. Soll AH, Achord JL, Bozymski G, Brooks S, Lanza F, Lyon D, et al. Medical treatment of peptic ulcer disease: practice guidelines. JAMA. 1996;275(8):622-9.

60. Walsh JH, Peterson WL. The treatment of Helicobacter pylori infection in the management of peptic ulcer disease. N Engl J Med. 1995;333(15):984-91.

61. Yuan Y, Padol IT, Hunt RH. Peptic ulcer disease today. Nat Clin Pract Gastroenterol Hepatol. 2006;3(2):80-9.

62. Mizokami Y, Oda K, Funao N, Nishimura A, Soen S, Kawai T, et al. Vonoprazan prevents ulcer recurrence during long-term NSAID therapy: randomised, lansoprazole-controlled non-inferiority and single-blind extension study. Gut. 2018;67(6):1042-51.

63. Vernon AH, Ferzoco SJ, Ashley SW, Feldman M. Surgical management of peptic ulcer disease. Official reprint from UpToDate www.uptodate.com. Literature review current through: Dec 2018| This topic last updated: Oct. $11 ; 2017$.

64. Lickstein L, Matthews J. Elective surgical management of peptic ulcer disease. Probl Gen Surg. 1997;14:37-53.

65. Connick P, Kolappan M, Crawley C, Webber DJ, Patani R, Michell AW, et al. Autologous mesenchymal stem cells for the treatment of secondary progressive multiple sclerosis: an open-label phase 2a proof-of-concept study. Lancet Neurol. 2012;11(2):150-6.

66. Wilson JG, Liu KD, Zhuo H, Caballero L, McMillan M, Fang X, et al. Mesenchymal stem (stromal) cells for treatment of ARDS: a phase 1 clinical trial. Lancet Respir Med. 2015;3(1):24-32.
67. Bianco P, Robey PG, Simmons PJ. Mesenchymal stem cells: revisiting history, concepts, and assays. Cell Stem Cell. 2008;2(4):313-9.

68. Khaldoyanidi S. Directing stem cell homing. Cell Stem Cell. 2008;2(3):198-200.

69. Han Y-M, Park J-M, Choi YS, Jin H, Lee Y-S, Han N-Y, et al. The efficacy of human placenta-derived mesenchymal stem cells on radiation enteropathy along with proteomic biomarkers predicting a favorable response. Stem Cell Res Ther. 2017;8(1):1-15.

70. Broudy VC. Stem cell factor and hematopoiesis. Blood J Am Soc Hematol. 1997;90(4):1345-64.

71. Gaberman E, Pinzur L, Levdansky L, Tsirlin M, Netzer N, Aberman Z, et al. Mitigation of lethal radiation syndrome in mice by intramuscular injection of 3D cultured adherent human placental stromal cells. PLoS ONE. 2013:8(6):e66549.

72. Galotto M, Berisso G, Delfino L, Podesta M, Ottaggio L, Dallorso S, et al. Stromal damage as consequence of high-dose chemo/radiotherapy in bone marrow transplant recipients. Exp Hematol. 1999;27(9):1460-6.

73. Potten CS. Extreme sensitivity of some intestinal crypt cells to $X$ and $\gamma$ irradiation. Nature. 1977;269(5628):518-21.

74. Hopewell JW, Calvo W, Jaenke R, Reinhold HS, Robbins ME, Whitehouse EM. Microvasculature and radiation damage. Recent Results Cancer Res. 1993;130:1-16. https://doi.org/10.1007/978-3-642-84892-6_1.

75. François S, Bensidhoum M, Mouiseddine M, Mazurier C, Allenet B, Semont $A$, et al. Local irradiation not only induces homing of human mesenchymal stem cells at exposed sites but promotes their widespread engraftment to multiple organs: a study of their quantitative distribution after irradiation damage. Stem cells. 2006;24(4):1020-9.

76. Gnecchi M, Zhang Z, Ni A, Dzau VJ. Paracrine mechanisms in adult stem cell signaling and therapy. Circ Res. 2008;103(11):1204-19.

77. Kuptsova N, Chang-Claude J, Kropp S, Helmbold I, Schmezer P, von Fournier D, et al. Genetic predictors of long-term toxicities after radiation therapy for breast cancer. Int J Cancer. 2008;122(6):1333-9.

78. Dar A, Goichberg P, Shinder V, Kalinkovich A, Kollet O, Netzer N, et al. Chemokine receptor CXCR4-dependent internalization and resecretion of functional chemokine SDF-1 by bone marrow endothelial and stromal cells. Nat Immunol. 2005:6(10):1038-46.

79. Zhao $\mathrm{Y}$, Zhang $\mathrm{H}$. Update on the mechanisms of homing of adipose tissue-derived stem cells. Cytotherapy. 2016;18(7):816-27.

80. Baek SJ, Kang SK, Ra JC. In vitro migration capacity of human adipose tissue-derived mesenchymal stem cells reflects their expression of receptors for chemokines and growth factors. Exp Mol Med. 2011;43(10):596-603.

81. De Ugarte DA, Morizono K, Elbarbary A, Alfonso Z, Zuk PA, Zhu M, et al. Comparison of multi-lineage cells from human adipose tissue and bone marrow. Cells Tissues Organs. 2003;174(3):101-9.

82. Schäffler A, Büchler C. Concise review: adipose tissue-derived stromal cells-basic and clinical implications for novel cell-based therapies. Stem Cells. 2007;25(4):818-27.

83. Kim W-S, Park B-S, Sung J-H. The wound-healing and antioxidant effects of adipose-derived stem cells. Expert Opin Biol Ther. 2009;9(7):879-87.

84. Atalay S, Coruh A, Deniz K. Stromal vascular fraction improves deep partial thickness burn wound healing. Burns. 2014;40(7):1375-83.

85. Rehman J, Traktuev D, Li J, Merfeld-Clauss S, Temm-Grove CJ, Bovenkerk $J$ E, et al. Secretion of angiogenic and antiapoptotic factors by human adipose stromal cells. Circulation. 2004;109(10):1292-8.

86. Quaglino D Jr, Nanney L, Ditesheim J, Davidson J. Transforming growth factor-beta stimulates wound healing and modulates extracellular matrix gene expression in pig skin: incisional wound model. J Investig Dermatol. 1991;97(1):34-42.

87. Abd-Elmenm S, Greish S, Atwa M, Fathelbab M. Evaluation of the role of adiposederived stem cells in the healing of Indomethacininduced gastric ulceration in rats. J Cell Sci Ther. 2016;7(4):1-5.

88. Rubina K, Kalinina N, Efimenko A, Lopatina T, Melikhova V, Tsokolaeva $Z$, et al. Adipose stromal cells stimulate angiogenesis via promoting progenitor cell differentiation, secretion of angiogenic factors, and enhancing vessel maturation. Tissue Eng Part A. 2009;15(8):2039-50.

89. Xia X, Chan KF, Wong GTY, Wang P, Liu L, Yeung BPM, et al. Mesenchymal stem cells promote healing of nonsteroidal anti-inflammatory drug-related peptic ulcer through paracrine actions in pigs. Sci Transl Med. 2019;11(516):eaat7455. 
90. Pai R, Ohta M, Itani RM, Sarfeh IJ, Tarnawski AS. Induction of mitogenactivated protein kinase signal transduction pathway during gastric ulcer healing in rats. Gastroenterology. 1998;114(4):706-13.

91. Yuan X, Han L, Fu P, Zeng H, Lv C, Chang W, et al. Cinnamaldehyde accelerates wound healing by promoting angiogenesis via up-regulation of PI3K and MAPK signaling pathways. Lab Investig. 2018;98(6):783-98.

92. Jones MK, Sarfeh IJ, Tarnawski AS. Induction of in vitro angiogenesis in the endothelial-derived cell line, EA hy926, by ethanol is mediated through PKC and MAPK. Biochem Biophys Res Commun. 1998;249(1):118-23.

93 Gao F, Chiu S, Motan D, Zhang Z, Chen L, Ji H, et al. Mesenchymal stem cells and immunomodulation: current status and future prospects. Cell Death Dis. 2016;7(1):e2062.

94. Domenis R, Cifù A, Quaglia S, Pistis C, Moretti M, Vicario A, et al. Pro inflammatory stimuli enhance the immunosuppressive functions of adipose mesenchymal stem cells-derived exosomes. Sci Rep. 2018;8(1):1-11.

95. Liu L, Chiu P, Lam P, Poon C, Lam C, Ng E, et al. Effect of local injection of mesenchymal stem cells on healing of sutured gastric perforation in an experimental model. J Brit Surg. 2015;102(2):e158-68.
96. Chang Q, Li Y, Wang C-Z, Zhang W-H, Hu Y-Z, Wu B-Y. In vivotransplantation of bone marrow mesenchymal stem cells accelerates repair of injured gastric mucosa in rats. Chin Med J. 2012;125(6):1169-74.

97. Hayashi Y, Tsuji S, Tsujii M, Nishida T, Ishii S, lijima H, et al. Topical transplantation of mesenchymal stem cells accelerates gastric ulcer healing in rats. Am J Physiol Gastrointest Liver Physiol. 2008;294(3):G778-86.

98. Alazzouni AS, Fathalla AS, Gabri MS, Dkhil MA, Hassan BN. Role of bone marrow derived-mesenchymal stem cells against gastric ulceration: histological, immunohistochemical and ultrastructural study. Saudi J Biol Sci. 2020;27(12):3456-64.

99. El Kasaby A, Ghaly M, Abo Zeid A, Fayed I. Therapeutic potential of adipose derived mesenchymal stem cells in regeneration of gastric ulcer in rats. J Med Histol. 2017;1 (2):190-201.

\section{Publisher's Note}

Springer Nature remains neutral with regard to jurisdictional claims in published maps and institutional affiliations.
Ready to submit your research? Choose BMC and benefit from:

- fast, convenient online submission

- thorough peer review by experienced researchers in your field

- rapid publication on acceptance

- support for research data, including large and complex data types

- gold Open Access which fosters wider collaboration and increased citations

- maximum visibility for your research: over $100 \mathrm{M}$ website views per year

At BMC, research is always in progress.

Learn more biomedcentral.com/submissions 